\title{
Optimal Regional Conjunctive Water Management
}

\author{
Jay E. Noel, B. Delworth Gardner, and Charles V. Moore
}

\begin{abstract}
An optimal control model is used to determine the socially optimal spatial and temporal allocation of groundwater and surface water among agricultural and urban uses. The control model is described briefly and its advantages over other dynamic models are enumerated. Optimal rates of groundwater pumpage over the planning horizon were highly sensitive to increasing energy costs. Groundwater basins are shown to react differently to alternative economic and hydrological parameters. In a dynamic setting, a policy of pump taxes was shown empirically to be superior to pro-rata quotas and uncontrolled pumpage.
\end{abstract}

Key words: control model, groundwater, energy cost, pro-rata allocation, Pigovian taxation.

The severe drought in the western United States in 1976-78 brought the problems of allocating extremely limited water resources to the attention of agriculturalists and urbanites alike. Greatly reduced surface water supplies exacerbated the already critical pressure on remaining groundwater stocks in the same areas.

The chronic overdraft of many western states groundwater basins can be attributed directly to their common pool nature. The lack of explicit property rights to groundwater stocks results in individual users of the resource evaluating only their own private pumping costs in their decision framework and implicitly assigning a zero opportunity cost to the stock portion of the resource. Thus, the private decision does not take into account any user cost and results in a divergence in the private and the social optimal rate of pumping. ${ }^{1}$

\footnotetext{
Jay E. Noel is a resource economist with Auslam and Associates, Sacramento, California. B. Delworth Gardner is Director of Giannini Foundation, Department of Agricultural Economics, University of California, Davis, and University of California, Berkeley. Charles V. Moore is an agricultural economist, ESCS, USDA, at Davis, California.

Giannini Foundation Paper No. 556.

This research was supported in part by the Office of Water Technology. USDI Matching Fund Program P.L. 88-379, Project B-187-CAL.

${ }^{1}$ Scott defines user cost of a natural resource as "the present value of future profit foregone by a decision to produce a unit of output today." Although this definition is used in the context of a profit-maximizing firm, it also applies to the water resource problem and refers to the existence value of the stock.
}

The objective of this paper is to describe briefly an optimal control model which can be used to determine the socially optimal spatial and temporal allocation of groundwater and surface water among agricultural and urban uses. The control model is then applied to a representative region of California under several sets of energy costs. Two policies, prorata allocation and taxation, are evaluated empirically as alternatives for accounting for externalities due to the common pool problem.

\section{The Conceptual Framework}

Several authors have investigated the conjunctive use of groundwater and surface water using various techniques. Buras developed a dynamic programming algorithm to solve the problem of conjunctive use of reservoirs and aquifers. His operating policy, however, considered the physical system as a single unit and thus ignored differences in hydrology that occur in a complex groundwater system. Burt (1964, 1966, 1967a, b) utilized a mathe matical programming approach to develop a demand function for irrigation water used in a dynamic programming formulation of the aquifer management problem. Bredehoeft and Young used a simulation model to estimate the solution of problems involving the development of a stream-aquifer system in an economic model of irrigation. Bear and Levin studied optimal utilization of an aquifer as one element of a 
water resource system. They provided a theoretical framework in which a demand function for water is an integral part of an aquifer model. Gisser and Mercado (1972, 1973) also integrate the demand function for water into a hydrologic model.

The model proposed in this paper is a linear quadratic control model (LQCM) and is composed of two basic parts, $(a)$ an economic component and $(b)$ a hydrologic component. The economic component contains a derived demand model, a stock opportunity cost model, and an urban demand model. The derived demands are obtained from a linear programming model. The use of linear programming to develop demand functions for agricultural water is rationalized in Moore and Hedges and Gisser. The stock opportunity cost model is a set of marginal pumping cost functions which are estimated so that the stock value of the resource can be derived. Finally, urban demand functions were estimated by an indirect method so that the LQCM can allocate water efficiently between the two sectors.

The hydrologic component of the LQCM is comprised of a set of equations of motion for the surface water reservoirs and groundwater basins. The former are estimated from data obtained from a surface water hydrology model, while the latter are a set of simultaneous equations estimated from data obtained from a finite element groundwater model. These equations indicate the changes that will occur in groundwater depths, given various pumping and recharge rates and also account for subsurface flow between basins.

The LQCM maximizes the value of economic components subject to the constraints implied by the hydrologic component. This particular model extends previous work in several ways. First, there is a direct interaction in the LQCM between a complex multibasin aquifer-surface water system and the demands for water. Second, the LQCM is solved by an algorithm based on Pontryagin et al. maximum principle, which provides an advantage over other work using dynamic programming, which limits the number of state and control variables. Finally, the use of the LQCM allows direct calculation of the user cost of groundwater. Both Kelso and Renshaw discuss the importance of including stock values in determining optimal water allocation. By using the LQCM, it is possible to maximize the value of both the stock and current value components of the water resource simultaneously, thereby allowing the calculation of the socially optimal spatial and temporal allocation.

\section{Application of the Conceptual Framework}

The geographical setting, Yolo County, located in the southwest corner of the Sacramento Valley, was selected for several reasons. It provides an example of a region in which conjunctive use of groundwater and surface water has evolved without any particular centralized planning (California Department of Water Resources). Several water agencies have areas of jurisdiction within the county and most if not all of each agency's planning is independent of the others with decisions being made to maximize private rather than overall social value of the water.

The county has a highly variable supply of surface water from Clear Lake, Indian Valley Reservoir, and the Sacramento River-Colusa Drain complex, used almost exclusively for irrigation. Groundwater supplies a more costly but more dependable source of water to both agricultural and urban users. The aquifer was partitioned into six basins for modeling purposes and follows the work done by hydrologists Scott and Scalmanini. The partitioning permitted the model to allocate water spatially and took account of unequal pumping lifts throughout the aquifer. There was also the problem of unequal specific yields throughout the aquifer, and the division of the aquifer into several basins permitted specification of storage capacities reflecting yields. The division of the aquifer required that the subsurface inflows and outflows between the six basins be accounted for in the model. Burt (1974) developed an approximately optimal decision rule where the subsurface flow between two basins in the same aquifer is explicitly contained in the model. For the model reported here, the subsurface flow is calculated by the groundwater model. Thus, the coefficients of the groundwater stock variables contain the effects of the subsurface flow term.

The LQCM used for determining allocations of water resources in Yolo County can be represented as follows:

$$
\text { (1) } \begin{array}{r}
\operatorname{Max} W=R R^{\prime} u_{t}-1 / 2 u_{t}{ }^{\prime} R u_{t} \\
-K K^{\prime} y_{t}+y_{t}{ }^{\prime} K y_{t},
\end{array}
$$

subject to 


$$
\begin{gathered}
y_{t}=A y_{t-1}-B u_{t-1}+C x_{t-1}+\mathbf{d}, \\
y_{t}-y^{*}{ }_{t} \leq 0, \\
u_{t}-u^{*}{ }_{t} \leq 0, \text { and } \\
y_{t} \geq 0 \quad u_{t} \geq 0 .
\end{gathered}
$$

The welfare function [equation (1)] is an explicit economic measure of welfare. It is composed of two parts. Producer and consumer surplus measures the economic value of the flow component of the water resource base. The consumer surplus is associated with the urban sector demand functions, while the producer surplus represents economic rent available to the agricultural sector. ${ }^{2}$ The second part is a social surplus for the stock portion of the water resource base. It measures the returns to the stock that could be gained from monopoly control. The social surplus increases as stocks increase and pumping costs decrease, ceteris paribus; and, alternatively, the social surplus decreases as stocks diminish and pumping costs increase. Note that these components are inversely related. The consumer and producer surplus components relate to flows and increase at a diminishing rate with increasing water use; however, as water use increases stocks diminish and the rents associated with this component decrease at an

${ }^{2}$ This measure has been used by Samuelson and later Takayama and Judge to measure social welfare. Mishan discusses the assumptions of this approach to social welfare measurement. increasing rate. Thus, the model maximizes the value of the water resource base by equating the net marginal value of the flow to the opportunity cost or marginal value of the stock in that period. ${ }^{3}$

The welfare function is subject to two sets of constraints. The first set [equation (2)] is the equations of motion or first-order difference equations describing the physical system. This is a reduced-form system, which in this study is a linear approximation to a complex physical system. $A, B$, and $C$ are specified as time invariant matrices and $\mathbf{d}$ is a vector of constants. The second set of constraints [equations (3), (4), and (5)] respresents the physical, institutional, and nonnegativity conditions on the stocks and flows of water. These constraints are not applied to every scenario posed by the model but rather act as individual scenario conditions so that resulting allocation patterns and effects on social welfare can be observed.

\section{The Results}

One reason for using an optimal control model was that it allowed direct calculation and interpretation of the user costs associated with temporal allocations. Table 1 presents the net

\footnotetext{
${ }^{3}$ The net marginal value is defined as the marginal value of water net of water cost. A more detailed description of the empirical model and the analytical necessary conditions for achieving an

\begin{tabular}{|c|c|c|c|c|c|c|c|c|}
\hline \multirow[b]{2}{*}{ Groundwater Basin } & \multirow[b]{2}{*}{ Value Measure } & \multicolumn{7}{|c|}{ Value (dollars/acre-foot) } \\
\hline & & 1977 & 1980 & 1985 & 1990 & 1995 & 2000 & 2005 \\
\hline Cache Creek & $\begin{array}{l}\text { stock user costs } \\
\text { net marginal values } \\
\text { transformed user costs }\end{array}$ & $\begin{array}{r}28.79 \\
5.68 \\
6.01\end{array}$ & $\begin{array}{r}23.15 \\
5.24 \\
4.84\end{array}$ & $\begin{array}{r}16.19 \\
3.20 \\
3.38\end{array}$ & $\begin{array}{r}11.33 \\
2.24 \\
2.37\end{array}$ & $\begin{array}{l}7.79 \\
1.52 \\
1.62\end{array}$ & $\begin{array}{l}4.93 \\
0.93 \\
1.03\end{array}$ & $\begin{array}{l}1.94 \\
0.26 \\
0.40\end{array}$ \\
\hline Upper Cache-Putah & $\begin{array}{l}\text { stock user costs } \\
\text { net marginal values } \\
\text { transformed user costs }\end{array}$ & $\begin{array}{r}30.00 \\
8.19 \\
8.73\end{array}$ & $\begin{array}{r}24.47 \\
7.64 \\
7.12\end{array}$ & $\begin{array}{r}17.32 \\
4.71 \\
5.04\end{array}$ & $\begin{array}{r}12.06 \\
3.01 \\
3.51\end{array}$ & $\begin{array}{l}8.05 \\
2.14 \\
2.34\end{array}$ & $\begin{array}{l}4.76 \\
1.21 \\
1.38\end{array}$ & $\begin{array}{l}1.67 \\
0.31 \\
0.47\end{array}$ \\
\hline Plainfield Ridge & $\begin{array}{l}\text { stock user costs } \\
\text { net marginal values } \\
\text { transformed user costs }\end{array}$ & $\begin{array}{r}1,214.10 \\
61.13 \\
240.39\end{array}$ & $\begin{array}{r}653.10 \\
61.13 \\
129.32\end{array}$ & $\begin{array}{r}241.20 \\
61.13 \\
47.77\end{array}$ & $\begin{array}{l}83.57 \\
13.06 \\
16.55\end{array}$ & $\begin{array}{r}21.53 \\
3.03 \\
4.26\end{array}$ & $\begin{aligned} & 0.87 \\
\simeq & 0.0 \\
& 0.17\end{aligned}$ & $\begin{array}{l}\simeq 0.00 \\
\simeq 0.00 \\
\simeq 0.00\end{array}$ \\
\hline Lower Cache-Putah & $\begin{array}{l}\text { stock user costs } \\
\text { net marginal values } \\
\text { transformed user costs }\end{array}$ & $\begin{array}{r}149.58 \\
9.83 \\
10.62\end{array}$ & $\begin{array}{r}118.63 \\
7.81 \\
8.42\end{array}$ & $\begin{array}{r}79.25 \\
5.17 \\
5.63\end{array}$ & $\begin{array}{r}51.08 \\
3.30 \\
3.63\end{array}$ & $\begin{array}{r}30.07 \\
1.94 \\
2.13\end{array}$ & $\begin{array}{r}15.76 \\
0.94 \\
1.12\end{array}$ & $\begin{array}{l}4.53 \\
0.18 \\
0.32\end{array}$ \\
\hline Colusa & $\begin{array}{l}\text { stock user costs } \\
\text { net marginal values } \\
\text { transformed user costs }\end{array}$ & $\begin{array}{r}27.94 \\
7.10 \\
7.66\end{array}$ & $\begin{array}{r}23.18 \\
5.88 \\
6.35\end{array}$ & $\begin{array}{r}16.79 \\
4.25 \\
4.60\end{array}$ & $\begin{array}{r}12.04 \\
3.04 \\
3.30\end{array}$ & $\begin{array}{l}8.50 \\
1.95 \\
2.33\end{array}$ & $\begin{array}{l}5.65 \\
1.37 \\
1.55\end{array}$ & $\begin{array}{l}2.49 \\
0.43 \\
0.68\end{array}$ \\
\hline East Yolo & $\begin{array}{l}\text { stock user costs } \\
\text { net marginal values } \\
\text { transformed user costs }\end{array}$ & $\begin{array}{r}12.23 \\
2.44 \\
2.66 \\
\end{array}$ & $\begin{array}{r}10.06 \\
2.00 \\
2.19 \\
\end{array}$ & $\begin{array}{l}7.22 \\
1.41 \\
1.57\end{array}$ & $\begin{array}{l}5.14 \\
1.02 \\
1.12 \\
\end{array}$ & $\begin{array}{l}3.60 \\
0.72 \\
0.78 \\
\end{array}$ & $\begin{array}{l}2.35 \\
0.44 \\
0.51 \\
\end{array}$ & $\begin{array}{l}0.99 \\
0.12 \\
0.22 \\
\end{array}$ \\
\hline
\end{tabular}
optimal solution is contained in Noel.
}

Table 1. Stock User Costs, Net Marginal Values, and Transformed User Costs (1977-2005, $\$ \mathbf{\$ 0 . 0 4 5} / \mathbf{k w h}$.) 
marginal values, stock user costs, and transformed user costs associated with the groundwater allocations listed in table 2. Surface water stock values are not included in table 1 because the surface water distribution system constraint limits the amount of surface water which can be used in any period to less than would have been allocated in the unconstrained solution. This restriction increased the net marginal value of the surface water in any time period to a level greater than the existing reservoir user cost in that time period.

The stock user cost for all basins except Plainfield Ridge can be interpreted as the present value of the loss in social surplus if one more acre-foot were allocated for use in the specific time period. For example, if one more acre-foot of water were used from the Lower Cache-Putah basin than is socially optimal, the value of the stock would diminish by $\$ 149.58$. The user cost figures given for Plainfield Ridge are not an accurate estimate of the true user cost because the lower bound constraint on the depth of the water table was reached. This constraint assumes that the volume of stored water associated with a depth greater than 420 feet is zero. Even though somewhat arbitrary, the lack of data on groundwater storage beneath $\mathbf{4 2 0}$ feet made the constraint necessary.

The transformed user costs are the present value of the stock in terms of current use. The transformation was made by the model to allocate water optimally between time periods. Note that the transformed user costs and net marginal values are approximately equal in each time period for each basin except Plainfield Ridge. Differences are due to rounding errors associated with use of the algorithm. It should be noted that these transformed user costs are a measure of the external costs that are imposed on other pumpers under the common property situation where private decision making on the part of individual users of the groundwater basins is based solely on private rather than the social cost of pumping a unit of water. Except for Plainfield Ridge, the extreme values of transformed user cost is $\$ 10.62$ for Lower Cache-Putah and \$2.66 for East Yolo. This indicates that different basins even in the same aquifer can exhibit different external costs. The magnitude of these costs can serve as at least one measure of whether or not governmental intervention into the allocative process is warranted. The differences

Table 2. Optimal Temporal Groundwater and Surface Water Allocations (1977-2005, \$0.045/ Kwh.)

\begin{tabular}{|c|c|c|c|c|c|c|c|c|}
\hline \multirow[b]{2}{*}{ Groundwater Basin } & \multirow[b]{2}{*}{ Water Supply } & \multicolumn{7}{|c|}{ (Acre-Feet) } \\
\hline & & 1977 & 1980 & 1985 & 1990 & 1995 & 2000 & 2005 \\
\hline \multirow[t]{2}{*}{ Cache Creek } & $\begin{array}{l}\text { surface } \\
\text { agriculture }\end{array}$ & 15,646 & 15,646 & 15,646 & 15,646 & 15,646 & 15,646 & 15,646 \\
\hline & groundwater & 47,525 & 47,586 & 47,663 & 47,747 & 47,926 & 48,504 & 50,567 \\
\hline \multirow[t]{3}{*}{ Upper Cache-Putah } & $\begin{array}{l}\text { surface } \\
\text { agriculture }\end{array}$ & 91,955 & 91,955 & 91,955 & 91,955 & 91,955 & 91,955 & 91,955 \\
\hline & $\begin{array}{l}\text { groundwater } \\
\text { urban }\end{array}$ & 33,859 & 33,872 & 33,967 & 34,251 & 34,982 & 36,825 & 41,361 \\
\hline & groundwater & 1,344 & 2,073 & 2,234 & 2,394 & 2,394 & 2,394 & 2,394 \\
\hline \multirow[t]{2}{*}{ Plainfield Ridge } & $\begin{array}{l}\text { surface } \\
\text { agriculture }\end{array}$ & 3,395 & 3,395 & 3,395 & 3,395 & 3,395 & 3,395 & 3,395 \\
\hline & groundwater & 0 & 0 & 0 & 7,492 & 12,879 & 15,601 & 0 \\
\hline \multirow[t]{3}{*}{ Lower Cache-Putah } & $\begin{array}{l}\text { surface } \\
\text { agriculture }\end{array}$ & 36,605 & 36,605 & 36,605 & 36,605 & 36,605 & 36,605 & 36,605 \\
\hline & $\begin{array}{l}\text { groundwater } \\
\text { urban }\end{array}$ & 139,670 & 141,690 & 146,050 & 152,320 & 161,620 & 175,700 & 197,340 \\
\hline & groundwater & 17,763 & 21,870 & 24,199 & 26,503 & 27,467 & 29,149 & 29,149 \\
\hline \multirow[t]{2}{*}{ Colusa } & $\begin{array}{l}\text { surface } \\
\text { agriculture }\end{array}$ & 179,130 & 179,130 & 179,130 & 179,130 & 179,130 & 179,130 & 179,130 \\
\hline & groundwater & 93,909 & 93,511 & 93,127 & 93,023 & 93,459 & 96,191 & 110,580 \\
\hline \multirow[t]{3}{*}{ East Yolo } & $\begin{array}{l}\text { surface } \\
\text { agriculture }\end{array}$ & 130,870 & 130,870 & 130,870 & 130,870 & 130,870 & 130,870 & 130,870 \\
\hline & $\begin{array}{l}\text { groundwater } \\
\text { urban }\end{array}$ & 59,571 & 59,548 & 59,527 & 59,536 & 59,628 & 60,054 & 61,904 \\
\hline & groundwater & 8,289 & 10,427 & 11,051 & 11,629 & 12,926 & 13,528 & 13,528 \\
\hline
\end{tabular}


in net marginal values and also in user costs in the six basins indicate potentials for economic intra and interbasin transfers of groundwater.

Table 2 contains the optimal spatial and temporal allocation of groundwater and surface water suggested by the model under a $4.5 \notin$ electrical power cost scenario. Several observations can be made about these results. The amount of groundwater used for agricultural production generally increases over time. Several economic factors determine the temporal allocation of water in the model. Factors which limit the quantity allocated to a specific period are $(a)$ increased pumping costs for the remainder of the planning horizon for those basins having declining water tables and $(b)$ lower marginal values from additional quantities of water used in that time period. The factors tending to increase the quantity used per period are $(a)$ time preference reflected by the discount rate and $(b)$ high net marginal values on low rates of water usage. The wide range of agricultural groundwater pumpages (0.0 to 141,690 acre-feet in 1980) illustrates quite dramatically the variability in optimal groundwater allocations that can exist in a single aquifer when both the economic and physical parameters in each basin are considered in the decision-making process.

Table 2 also contains urban groundwater allocations which are based on "need" projections. The projections are based on urban water requirement studies done by several engineering consulting firms, and by using an urban water projection model developed by Savage and Helweg for estimating the impact of population and areal growth patterns for water use rates for the City of Davis. The projections were used as constraints on urban allocations because early control model runs, based on the hypothetical urban demand func- tions estimated for this study, allocated certain amounts to the urban areas in excess of existing or projected distribution system capacity.

The amount of groundwater needed by urban users moves from $6.8 \%$ of the total amount of groundwater used in all basins in 1977 to $8.6 \%$ of the total by 2,005 . This represents a small proportion of the total amount of groundwater used in any period. Thus, the impacts on groundwater stocks by urban usage is rather insignificant for any basin as a whole. This suggests that concern that urban growth will affect adversely agricultural pumpage and pumping cost is largely unfounded.

The surface water allocations shown in table 2 can be explained by the surface water cost used in this model: namely, those that existed in 1977 were selected due to the difficulty in predicting the future price-setting actions of the various agencies allocating surface water. Because surface water costs are substantially less than groundwater pumping costs, surface water allocations depend on the relative net marginal values of this water between the various basins and on the capacity of the distribution system. Surface water allocations are limited in every power cost scenario by constraints associated with either reservoir water distribution capacity or the amount of surface water that can be obtained from the Sacramento River-Colusa Drain complex. The surface water allocations listed in table 2 are thus constrained allocations.

Table 3 contains the groundwater depths and surface water stocks associated with the optimal allocations contained in table 2. Note that in three of the six basins the water table decreases over time, while in the remaining three it increases. This set of figures indicates quite strikingly that treating the whole

Table 3. Groundwater Depths and Surface Water Stocks (1977-2005, $\$ 0.045 / \mathbf{K w h}$.)

\begin{tabular}{|c|c|c|c|c|c|c|c|}
\hline \multirow[b]{2}{*}{ Groundwater Basin } & \multicolumn{7}{|c|}{ Depth to Groundwater (feet) } \\
\hline & 1977 & 1980 & 1985 & 1990 & 1995 & 2000 & 2005 \\
\hline Cache Creek & 64 & 69 & 74 & 77 & 80 & 81 & 82 \\
\hline Upper Cache-Putah & 41 & 40 & 39 & 38 & 38 & 39 & 39 \\
\hline Plainfield Ridge & 105 & 119 & 145 & 190 & 262 & 385 & $>420$ \\
\hline Lower Cache-Putah & 53 & 56 & 61 & 65 & 71 & 76 & 81 \\
\hline Colusa & 55 & 50 & 45 & 42 & 41 & 40 & 41 \\
\hline East Yolo & 20 & 18 & 15 & 13 & 12 & 11 & 11 \\
\hline \multicolumn{8}{|c|}{ Effective Storage (acre-feet) } \\
\hline Clear Lake & 315,000 & 315,000 & 315,000 & 315,000 & 315,000 & 315,000 & 315,000 \\
\hline Indian Valley & 138,789 & 139,574 & 139,857 & 139,893 & 139,893 & 139,893 & 139,893 \\
\hline
\end{tabular}


groundwater basin in Yolo County as an aggregate unit would miss the sizeable variation in optimal utilization of the groundwater in the various basins composing the aquifer. These data show that the choice of a planning unit for determining optimal water allocations is very important. If the unit chosen is too large, and a single utilization rate were used throughout, groundwater mighe be seriously under- or over-utilized. Even more subdivision of the aquifer studied might have revealed even more variation in optimal utilization rates, but further analysis was infeasible.

Effects of rising energy costs. Energy costs can have an important influence on whether the model indicates a groundwater basin with an increasing or decreasing water table. For example, Upper Cache-Putah basin would be mined under a $2.6 c$ energy cost assumption but would have a rising water table initially under the $8 \subset$ energy cost assumption (fig. 1). The remaining basins move in the same direction as indicated in table 4 at alternative energy cost assumptions. In those basins where groundwater use exceeds recharge under a $4.5 \notin$ energy cost, the effect of higher energy costs is to slow down the rate of mining.

Table 4 illustrates the impact increasing energy costs have on temporal water allocation, using the Cache Creek basin as an example. Surface water allocations depend upon the net marginal value of water in a single basin relative to the net marginal values in other competing basins. For Cache Creek, the allocations are reasonably constant over time. Groundwater pumpage at any time period decreases as expected as energy costs increase, because the net marginal value of water is lower and the stock value is higher.

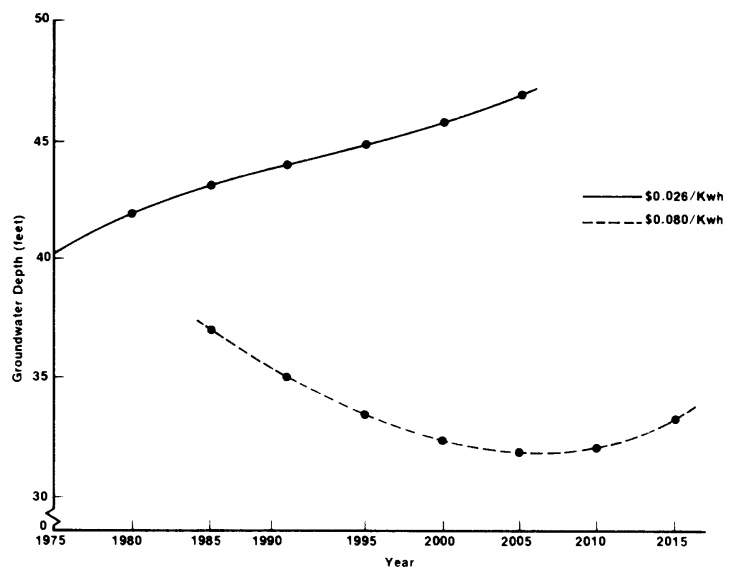

Figure 1. Impact of constant energy cost on Upper Cache-Putah Basin groundwater depth (\$0.026/kwh. and $\$ 0.080 / \mathbf{k w h} ., 1975-2015)$

\section{Policies to Reduce Misallocation of Groundwater}

In this section two policies are analyzed empirically that could be utilized to achieve a more socially preferred allocation of groundwater. The focus here is on groundwater because of the lack of any definitive empirical studies which evaluate the impact of various policies on the social value of groundwater. This is not meant to infer that surface water allocation is unimportant. Quite to the contrary, surface water sources supply almost one-half the county's agricultural water demands.

The control model provided the socially efficient allocations of the surface water resource. If contractual arrangements were made on a "market value" rather than a "first come-first serve" arrangement, then

Table 4. Increasing Energy Cost Impacts on Temporal Surface and Groundwater Allocations, 1975-2015-Cache Creek Basin (acre-feet)

\begin{tabular}{|c|c|c|c|c|c|c|c|c|c|c|c|}
\hline $\begin{array}{l}\text { Energy } \\
\text { Cost } \\
\text { (\$/Kwh.) }\end{array}$ & $\begin{array}{l}\text { Water } \\
\text { Supply }\end{array}$ & 1975 & 1977 & 1980 & 1985 & 1990 & 1995 & 2000 & 2005 & 2010 & 2015 \\
\hline 0.026 & $\begin{array}{l}\text { surface water } \\
\text { groundwater }\end{array}$ & $\begin{array}{l}14,465 \\
51,714\end{array}$ & $\begin{array}{l}14,465 \\
51,748\end{array}$ & $\begin{array}{l}14,465 \\
51,790\end{array}$ & $\begin{array}{l}14,465 \\
51,850\end{array}$ & $\begin{array}{l}14,465 \\
51,932\end{array}$ & $\begin{array}{l}14,465 \\
52,148\end{array}$ & $\begin{array}{l}14,465 \\
52,887\end{array}$ & $\begin{array}{l}14,465 \\
54,073\end{array}$ & & \\
\hline 0.045 & $\begin{array}{l}\text { surface water } \\
\text { groundwater }\end{array}$ & & $\begin{array}{l}15,645 \\
47,525\end{array}$ & $\begin{array}{l}15,645 \\
47,586\end{array}$ & $\begin{array}{l}15,645 \\
47,663\end{array}$ & $\begin{array}{l}15,645 \\
47,747\end{array}$ & $\begin{array}{l}15,645 \\
47,926\end{array}$ & $\begin{array}{l}15,645 \\
48,504\end{array}$ & $\begin{array}{l}15,645 \\
50,567\end{array}$ & & \\
\hline 0.065 & $\begin{array}{l}\text { surface water } \\
\text { groundwater }\end{array}$ & & & $\begin{array}{l}17,122 \\
42,533\end{array}$ & $\begin{array}{l}17,122 \\
43,012\end{array}$ & $\begin{array}{l}17,122 \\
43,082\end{array}$ & $\begin{array}{l}17,122 \\
43,204\end{array}$ & $\begin{array}{l}17,122 \\
43,566\end{array}$ & $\begin{array}{l}17,122 \\
44,832\end{array}$ & $\begin{array}{l}17,122 \\
47,980\end{array}$ & \\
\hline 0.080 & $\begin{array}{l}\text { surface water } \\
\text { groundwater }\end{array}$ & & & & $\begin{array}{l}15,793 \\
38,949\end{array}$ & $\begin{array}{l}15,793 \\
38,990\end{array}$ & $\begin{array}{l}15,793 \\
39,040\end{array}$ & $\begin{array}{l}15,793 \\
39,158\end{array}$ & $\begin{array}{l}15,793 \\
39,550\end{array}$ & $\begin{array}{l}15,793 \\
40,952\end{array}$ & $\begin{array}{l}15,793 \\
44,450\end{array}$ \\
\hline
\end{tabular}


surface water would move toward a more socially efficient allocation. For example, if agricultural producers were allowed to bid for available water supplies, assured full property rights and perfect competition, they would bid the price up to the level of the marginal value of water utilized in production. Because the control model is based on exactly this type of allocation procedure, it is expected that surface allocation resulting from the "water market" arrangement would approximate the socially optimum allocation indicated by the control model.

The pro-rata groundwater policy. The prorata method is one that attacks the common pool problem by adjudicating annual groundwater quotas to overlying landowners. The quota most often recommended is established by restricting pumpage to the long-run mean recharge rate. This suggests that no mining of the resource should be permitted on the average.

Table 5 provides a comparison of the total value of the groundwater resource for the entire Yolo County aquifer under socially optimum conditions (no restrictions on temporal allocations of the resource in any basin) as opposed to a quota system, where the quota is limited to the mean recharge rate. This comparison is made under two energy cost scenarios and the results under both energy cost runs indicate that using a quota diminishes the potential social benefits to be derived from the resource. The $4.5 \notin$ energy cost scenario shows a much wider divergence from the optimal social value, however, than does the $6.5 c$ energy cost scenario. The percentage loss of social value under the $4.5 \%$ energy scenario ranges from $11 \%$ to $6 \%$ over the planning horizon, while for the $6.5 \notin$ energy scenario the range is only $4.4 \%$ to $1.1 \%$. As energy costs increase and the optimal amount of water to be used ir: any single period declines, the quota system comes closer to approximating the social value of the resource on a basin-wide basis.

From the above it is obvious that quotas will be least inefficient where the amount of water mining in the optimal allocation is small in relation to recharge. However, quotas always will be suboptimal if any economic mining of the resource is optimal, and their inefficiency will increase as transaction costs are taken into consideration. These costs would be in the form of administrating and policing the quota policy. The quota values listed in table 5 include none of these costs, and thus must be viewed as upper bounds and the differences are biased downwards. It should be noted here that this situation is not unique for quota policies. Any policy which controls the use of a common property resource in a more socially preferred manner probably would require a new institutional structure and therefore would require new transaction costs.

Laissez-faire groundwater policy. The inclusion of transaction costs in the calculus of considering policy changes creates the possibility that the status quo may offer the "best" that can be done in terms of maximizing the social value of the water resource. Table 6 compares the value of the groundwater of Yolo County under a purely private decision-making situation where each pumper decides independently how much water to take from the aquifer and the socially efficient situation where the negative externalities associated with private actions are taken into consideration. The user cost or stock value is assigned a zero value to represent the private allocation situation.

There is a large difference between the so-

Table 5. Yearly and Total Present Value of the Water Resource under Socially Efficient and Quota Allocations (1977-2010, \$0.045/Kwh. and \$0.065/Kwh.)

\begin{tabular}{|c|c|c|c|c|c|c|c|c|c|c|}
\hline $\begin{array}{l}\text { Energy } \\
\text { Cost } \\
\text { (\$/Kwh.) }\end{array}$ & $\begin{array}{l}\text { Value } \\
\text { Measure }\end{array}$ & 1977 & 1980 & 1985 & 1990 & 1995 & 2000 & 2005 & 2010 & Total $^{\mathbf{a}}$ \\
\hline 0.045 & $\begin{array}{l}\text { Social } \\
\text { Quota } \\
\text { Difference }\end{array}$ & $\begin{array}{r}22,122 \\
19,619 \\
2,493\end{array}$ & $\begin{array}{r}16,860 \\
15,224 \\
1,636\end{array}$ & $\begin{array}{r}12,820 \\
11,710 \\
1,110\end{array}$ & $\begin{array}{r}9,230 \\
8,530 \\
700\end{array}$ & $\begin{array}{r}\text { housan } \\
6,150 \\
5,730 \\
420\end{array}$ & $\begin{array}{r}4,710 \\
4,410 \\
300\end{array}$ & $\begin{array}{r}3,350 \\
3,150 \\
200\end{array}$ & & $\begin{array}{r}294,240 \\
268,750 \\
25,490\end{array}$ \\
\hline 0.065 & $\begin{array}{l}\text { Social } \\
\text { Quota } \\
\text { Difference }\end{array}$ & & $\begin{array}{r}19,185 \\
18,292 \\
893\end{array}$ & $\begin{array}{r}13,781 \\
13,696 \\
412\end{array}$ & $\begin{array}{r}9,840 \\
9,640 \\
200\end{array}$ & $\begin{array}{r}7,160 \\
7,040 \\
120\end{array}$ & $\begin{array}{r}5,160 \\
5,090 \\
70\end{array}$ & $\begin{array}{r}3,720 \\
3,670 \\
50\end{array}$ & $\begin{array}{r}2,830 \\
2,800 \\
30\end{array}$ & $\begin{array}{r}259,160 \\
252,410 \\
6,750\end{array}$ \\
\hline
\end{tabular}

\footnotetext{
a Represents total value of the water resource over the entire planning horizon.
} 
Table 6. Yearly and Total Present Value of the Water Resource under Socially Efficient and Private Decision Allocations (1977-2005, \$0.045/Kwh.)

\begin{tabular}{|c|c|c|c|c|c|c|c|c|}
\hline $\begin{array}{l}\text { Value } \\
\text { Measure }\end{array}$ & 1977 & 1980 & 1985 & 1990 & 1995 & 2000 & 2005 & Total $^{\mathrm{a}}$ \\
\hline & & & & $-(\$$ th & d) --- & 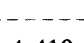 & & $\cdots$ \\
\hline Social & 22,112 & 16,860 & 12,820 & 9,230 & 6,150 & 4,410 & 3,120 & 294,240 \\
\hline Private & 18,068 & 14,694 & 10,485 & 7,174 & 5,103 & 3,612 & 2,565 & 241,322 \\
\hline Difference & 4,044 & 2,166 & 2,335 & 2,056 & 1,047 & 798 & 555 & 52,918 \\
\hline
\end{tabular}

a Represents total value of the water resource over the entire planning horizon.

cial optimum and the private optimum value of the water resource, much larger than the difference between the social optimum and the quota solution described above. These differences, however, are not directly comparable because they measure different things. The difference between the quota and the socially optimum value represents the returns foregone if the amount of groundwater usage is limited to a long-run mean recharge quota. The unrestricted pumping value is a measure of the external cost imposed on all water users by the failure of individual pumpers to take into account the total social costs of individual pumping. The total difference between the social optimum and the private solution is $\$ 52,918,000$ over the thirty-year-planning horizon. In comparing the unrestricted solution to the quota policy solution, it must be concluded that neither policy is efficient. However, the quota policy appears better to approximate the social optimum than does the unrestricted pumping policy. Thus, a policy to control groundwater use appears to be justified if the transaction costs are less than the costs of the externalities. Thus, even though it has been shown that the long-run recharge quota is not a "good" policy for reaching the true social value of the water resource, it can be used to control allocations so that the negative externalities are taken into consideration.

It appears, therefore, that a good case can be made for limiting the water pumped from the aquifer, unless there are opportunities for economically efficient transfers among basins on the surface through a market transfer process. If so, continued overdrafting would be justified only if the value of the transferred water at the margin were higher than the sum of the user costs, pumping costs, and transfer costs.

Pumping tax policy. An alternative policy for managing a groundwater basin that suffers from the problem of commonality of use is to levy a tax on pumping. This is a widely proposed solution to correct a divergence between private and social costs (Pigou). In this case the marginal private cost is simply the marginal cost of pumping to individual users. The marginal social cost includes as well the loss of productivity to individual users because of competitive pumping. The dominant problem with Pigovian solutions is the selection of the correct tax (Baumol). Milliman demonstrates that if the marginal value of a unit of water pumped is equated to the marginal social cost of pumping the water that a social optimum has been reached.

The necessary condition for the empirical model to allocate water optimally requires that the net marginal value of a unit of water used be equated to the transformed user cost. Because the marginal private pumping costs already have been subtracted from the marginal values, the transformed user cost actually measures the difference between the marginal social and marginal private cost of pumping a unit of water. As such, it represents the optimal marginal tax rate that is required to force private and social costs to converge.

Table 7 contains the optimal tax under a $4.5 \notin$ energy cost scenario. The results listed in the table indicate that the optimal tax structure is not a fixed levy over the entire planning horizon, but is rather a declining set of tax rates. The table results raise other issues. First, all tax rates are positive. At first glance this may appear somewhat surprising given that three of the six basins indicate rising water tables after the $4.5 \notin$ energy cost has been reached. Even with rising water tables, however, if an individual pumper did not extract a unit of water, the water table would rise somewhat higher than if the unit of water were extracted. This extraction thus increases the pumping costs of the other individuals using the aquifer.

In addition, the tax rates show a wide range 
Table 7. Optimal Tax Rate Schedule for the Yolo County Groundwater Basins (1977-2000, $\$ \mathbf{\$ 0 . 0 4 5 / K w h . )}$

\begin{tabular}{lrrrrrr}
\hline Groundwater Basin & 1977 & 1980 & 1985 & 1990 & 1995 & 2000 \\
\hline & & & & & & \\
& & & & & \\
Cache Creek & 6.01 & 4.84 & 3.38 & 2.37 & 1.62 & 1.03 \\
Upper Cache-Putah & 8.73 & 7.12 & 5.04 & 3.51 & 2.34 & 1.38 \\
Plainfield Ridge & 240.39 & 129.32 & 47.77 & 16.55 & 4.26 & 0.17 \\
Lower Cache-Putah & 10.62 & 8.42 & 5.62 & 3.63 & 2.13 & 1.12 \\
Colusa & 7.66 & 6.35 & 4.60 & 3.30 & 2.33 & 1.55 \\
East Yolo & 2.66 & 2.19 & 1.57 & 1.12 & 0.78 & 0.51 \\
\hline
\end{tabular}

of values, depending on several factors: $(a)$ the physical parameters of the individual basins; $(b)$ the costs associated with pumping a unit of groundwater; and $(c)$ the economic demands for current use (both for agriculture and urban use).

Finally, the tax rate declines over time under constant energy costs, a result to be expected since over time the stock values (user costs) decline. This reduces the disparity between the restricted pumping situation and the socially optimal allocation, and the tax rate correspondingly declines.

From an analytical viewpoint the two methods of dealing with commonality of water use offer very different lines of attack. Quota setting in effect imposes a tighter constraint on the resource than does taxation. Quota setting transfers the decision making from the private user to a central agency. Taxation allows greater flexibility because the decision on pumpage is left to the individual user. The tax simply becomes another component of the pumper's cost function and is taken into consideration when deciding how much water should be used in any time period. Baumol demonstrates that where an externality (technical) exists that taxes upon the generator of the externality are all that is required to produce an efficient allocation. Baumol argues that even if the level of taxation needs to be adjusted in a tâtonnement process to achieve the desired result, it is still the best way to correct the divergence between social and private cost.

\section{Concluding Remarks}

This paper has proposed a control model framework for determining the optimal spatial and temporal allocation of water in a complex hydrologic and economic setting. The advantage of this framework over past work done in the area of water resource allocation is the ability of the model to handle a large degree of disaggregation and to provide valuable economic and hydrologic information about the physical system with respect to its common pool nature. Thus, this paper demonstrates the usefulness of a framework that can take the interaction of several groundwater basins into consideration as the socially optimum allocations are determined. Two broad policy implications can be drawn from the results.

First, the areal size of a water resourceplanning unit must be chosen with care. The results presented in this paper illustrate quite dramatically that the six basins making up the Yolo County aquifer react differently to alternative economic and hydrologic parameters. In terms of policy, this means that designation of groundwater planning units should be based on economic and hydrologic parameters and not on political or geographical boundaries. The degree of hydrologic interdependence between different basins in the same aquifer, or between aquifers, is the key factor in determining any planning unit. These interdependencies are directly related to the common pool problem associated with groundwater use. If the interdependencies are not accounted for in the allocation decision, there will be a large reduction in the social value of the groundwater resource.

The second policy implication relates to the economic impacts associated with policy alternatives for moving current groundwater allocations to a more socially preferred set. Although taxation and pro-rata allocations have been suggested a number of times in the literature as institutional instruments to achieve a more socially optimal allocation of resources, the current framework has shown the change in social value of the resource that can be expected upon their implementation. The results indicate that both instruments will increase the social value of the groundwater re- 
source but that if any mining of the resource is contemplated, that taxation provides for the greatest social value of the groundwater being achieved.

\section{[Received June 1979; revision accepted December 1979.]}

\section{References}

Baumol, W. J. "On Taxation and the Control of Externalities." Amer. Econ. Rev. 62(1972):307-22.

Bear, J., and O. Levin. "Optimal Utilization of an Aquifer as an Element of Water Resources System.' Selected Works in Operations Research and Hydraulics, Published in Memory of Oded Levin. Haifa, Israel: Technion, 1970.

Bredehoeft, J. D., and R. A. Young. "The Temporal Allocation of Groundwater-A Simulation Approach." Water Resour. Res. 6(1970):3-21.

Buras, N. "Conjunctive Operations of Dams and Aquifers." J. Hydraulics 89(1963): 107-29.

Burt, O. R. "Economic Control of Groundwater Reserves." J. Farm Econ. 48(1966):632-47. . "Groundwater Management and Surface Water Development for Irrigation." Paper presented at joint meetings of the Operations Research Society of America and Institute of Management Sciences, San Juan, Puerto Rico, 17 Oct. 1974.

—. "Groundwater Management under Quadratic Criterion Functions." Water Resour. Res. 3(1967a):673-82.

" Optimal Resource Use over Time with an Application to Groundwater." Manage. Sci. 11(1964):80 93.

. "Temporal Allocation of Groundwater." Water Resour. Res. 3(1967b):45-56.

California Department of Water Resources. California Groundwater. Bull. No. 118, 1975.

Gisser, M. "Linear Programming Models for Estimating the Agricultural Demand Function for Imported
Water in the Pecos River Basin." Water Resour. Res. 6(1970): 1025-32.

Gisser, M., and A. Mercado. "Economic Aspects of Groundwater Resources and Replacement Flows in Semi-Arid and Agricultural Areas." Amer. J. Agr. Econ. 55(1973):461-6.

- " Integration of the Agricultural Demand Function For Water and the Hydrologic Model for the Pecos Basin." Water Resour. Res. 8(1972):1373-84.

Kelso, M. M. "The Stock Resource Value of Water." $J$. Farm Econ. 43(1961): 1112-29.

Milliman, J. W. "Commonality, the Price System, and the Use of Water Supplies." S. Econ. J. 22(1956):426-37.

Mishan, E. J. Cost-Benefit Analysis. New York: Praeger Publishers, 1976.

Moore, C. V., and T. R. Hedges. "A Method for Estimating the Demand for Irrigation Water." Agr. Econ. Res. 15(1963):131-5.

Noel, J. E. "Dynamic Water Management: An Optimal Control Approach." Ph.D. Thesis, University of California, Davis, 1979.

Pigou, A. C. The Economics of Welfare. London: Macmillan \& Co., 1932.

Pontryagin, L. S., V. S. Bollyonskii, R. V. Gamkreligze, and E. F. Michcheuko. The Mathematical Theory of Optimal Processes. New York: John Wiley \& Sons, 1962.

Renshaw, E. F. "The Management of Groundwater Reservoirs." J. Farm Econ. 45(1963):285-95.

Samuelson, P. A. "Spatial Price Equilibrium and Linear Programming." Amer. Econ. Rev. 42(1952):283-303.

Savage, M., and O. Helweg. Documentation for a City Water Demand Simulation Model. Dep. Civil Engin., University of California, Davis. 1978.

Scott, A. T. "The Theory of the Mine under Conditions of Certainty." Extractive Resources and Taxation, ed. Mason Gaffney. University of Wisconsin Press, 1967.

Scott, V. H., and J. C. Scalmanini. Investigation of Groundwater Resources: Yolo County, California. Dep. Water Sci. and Engin. Pap. No. 2006, University of California, Davis, Sep. 1975.

Takayama, T., and G. G. Judge. "An Interregional Price Equilibrium Model of the Agricultural Sector.' $J$. Farm Econ. 46(1964):349-65. 